\title{
Rushdie and the Problem of Exile
}

\section{Dr. Shadan Jafri}

Associate Professor

Dept. of English

Agra College

Agra, Uttar Pradesh, India

shadantanveer.1976@gmail.com

\begin{abstract}
Exile in the words of Wallace Stevens, is "a mind of winter" in which the pathos of summer and autumn as much as the potential of spring are nearby but unobtainable. Exile originated in the age-old practice of banishment. Once banished, the exile lives an anomalous and miserable life, with the stigma of being an outsider. Although it is true that anyone prevented from returning home is an exile, some distinctions can be made among exiles, refugees, expatriates and émigrés. Edward Said, in his work, Reflections on Exile, writes, "Refugees... are a creation of the twentieth-century state." The word "refugee" has become a political one, suggesting large herds of innocent and bewildered people requiring urgent international assistance, whereas "exile" carries with it, I think, a touch of solitude and spirituality. Expatriates voluntarily live in an alien country; usually for personal or social reasons...An émigré is anyone who emigrates to a new country. (181) In this paper, I will take up Salman Rushdie and his experience of exile and try to analyse and differentiate the two kinds of exiles he underwent in his career.
\end{abstract}

Keywords: Exile, Migrant, Native, Homelessness, Bonding. 
Our ancient literature, mythology and history contain popular, heroic, romantic, glorious, even triumphant episodes in an exile's life. But, at the same time, "true exile is a condition of terminal loss..." (173). Said writes, "Exiles are cut from their roots, their land, their past. They generally do not have armies or states, although they are often in search of them. Exiles feel, therefore, an urgent need to reconstitute their broken lives, usually by choosing to see themselves as part of a triumphant ideology or a restored people."(177) Therefore, it is not surprising to see many exiles who are novelists, chess-players, politicalactivists and intellectuals. The exile's new world, is often "unnatural and its unreality resembles fiction."(181) Georg Lukacs, in The Theory of the Novel wrote that the novel as a literary form is created out of the unreality of ambition and fantasy. It is a form of "transcental homelessness". Classical epics, Lukacs wrote; emanate from settled cultures, in which values are clear, identities stable, life unchanging. The European novel is grounded in precisely the opposite existence, that of a changing society in which an itinerant and disinherited middle-class hero or heroine seeks to construct a new world that somewhat resembles an old one left behind forever. Said writes, "No matter how well they may do, exiles are always eccentrics who feel their difference (even as they frequently exploit it) as a kind of orphan hood...Clutching difference like a weapon to be used with stiffened will, the exile jealously insists on his or her right to refuse to belong...Wilfulness, exaggeration, overstatement : these are characteristic styles of being an exile, methods for compelling the world to accept your vision... Composure and serenity are the last things associated with the work of exiles. Artists in exile are decidedly unpleasant, and their stubbornness insinuates itself into even in their exalted works." (182)

Dante in his The Divine Comedy, is banished from Florence, but uses eternity as a place for settling old scores. James Joyce chose to be in exile. He described his state of being in a letter as "alone and friendless". And although picking banishment as a way of life was 
rare, Joyce enjoyed and made a success out of it. Perhaps the most rigorous example of such writing is that of Theodor Adorno, the German-Jewish philosopher, critic and member of the Frankfurt School. Adorno's masterwork, Minima Moralia, subtitled 'Reflections from a Mutilated Life', is an autobiography written in exile. He writes that the only home truly available now, "though fragile and vulnerable, is in writing." Adorno uses the concept of "Phantasmogria" means a crowd or succession of dim or doubtfully real persons. The word was coined in England in 1802 and was later taken over into German literature.

Aijaz Ahmad names James, Conrad, Pound, Eliot, Picasso and Gertude Stein who experienced "suffocation in their own space of this globe; and yet left behind immense sources of genre and vocabulary far delineating that predominant image of the modern artist who lives as a literal stranger in a foreign and impersonal city and who, on the one hand, uses the condition of exile as the basic metaphor for modernity and even for the human condition itself, while, on the other, writing obsessively, copiously, of that very land which had been declared 'suffocating'. (Pg. 134)

Perhaps one of the most famous Indian writers to write on American Soil, Salman Rushdie has been influential worldwide as well as locally. Rushdie is an eclectic writer, who has written on many different topics and satirized many social issues. With more than fifteen different written works in publication, Salman Rushdie has influenced the world since 1975. His works cover a wide range, from fantasy to religion and non-fiction. With many different types of genres and such a great writing style, it is not hard to believe that such an author could be controversial, and that is, in fact what is most associated with Salman Rushdie. He is, if nothing else, extremely controversial.

Born in Bombay to Kashmiri Muslim parents, Salman Rushdie was raised as a Muslim. His paternal grandfather was a poet and his father was a Cambridge-educated man. Rushdie left Bombay at the age of fourteen to study at Rugby in England. It was here that he 
tasted his first bitter experience of racism when one of the boys, with whom he shared his study, wrote, "Wogs go home" on the wall over his chair (Glendenning 38). So hurt was Rushdie that he never wanted to return to England after that. But, in 1967 his parents migrated to Pakistan. He spent some time there after the completion of his school education. His parents persuaded him to join King's College in Cambridge and he returned to England to study for his graduate degree with History as the subject of his specialization. After graduation, he worked for a while in England as a stage actor and then as a copywriter in an advertising firm. Meanwhile, he was also very seriously working at becoming a writer. Rushdie, in fact wanted to become a writer since childhood. Rushdie says that the first writer he knew was Faiz Ahmad Faiz, a friend of his parents, "a kind of extra uncle" to him. He admired Faiz for combining public and social awareness and responsibility with intense lyricism and he decided he would be a writer like him. (Trivedi 12)

The interesting thing about his work-is that despite the variation in form and subject matter, certain ideas, literary and thematic concerns appear repeatedly in his works. From his entire body of work, it is clear that the most recurrent ideas or themes are that of migrancy and the writer's freedom to challenge authority which appear in all his works.

His own migration has certainly made him think a lot about the subject and right from Grimus (1979) his first novel, the theme has been repeated in every single work of his. Even though the book did not earn fame, it contains seeds of the competing claims of "native home" and "adopted home" for the migrant. Salman Rushdie's 1981 story Midnight's Children won the author worldwide acclaim. The satire of Indian history showed his appreciation of the fantastic as well as his ability to write with vigour and unique style. It won the "Booker McConnell Prize" in 1981 and again the "Booker of Booker Prize" in 1994. But, it was his first step towards controversy. It portrayed, Mrs. Indira Gandhi, the then Prime 
Minister of India, in an unfavourable light. Needless to say, supporters of the Gandhi family did not appreciate the portal, and called Rushdie a traitor to his culture.

Rushdie's third novel was Shame. It is set in Pakistan. The narrator in Shame is an expatriate who returns to Pakistan for an extended visit. The novel captures the abstract concept of shame on two levels-the national and the domestic. On the national level the main characters are thinly veiled caricatures of Zia ul Haq and Zulfikar Bhutto. On the marital plane, the men exhibit lack of Sharam (Shame) in their oppression of the womenfolk. Both aspects are conveyed through the narration of the migrant visitor who describes himself as a "translated man", standing between two cultures.

However, the book that got him into deep trouble was The Satanic Verses, his fourth novel. It was published in 1988 and became his most controversial work. This written work once again criticized and portrayed a famous and important character in an unfavourable light. This time it was none other than the Prophet Mohammed of Islam. The book was well received in the UK and the USA; it was banned in India since it hurts the religious sentiments of the Muslims and led to riots and killings in Bombay's Bhendi Bazaar. Soon, it was banned in Pakistan, Egypt, Saudi Arabia, Indonesia, South Africa and countries with large Muslim population. Rushdie's fate was sealed finally when on 14 February, 1989. Iran's Ayatollah Khomeini announced a "fatwa" against Rushdie, exhorting "Zealous Muslims" to execute him quickly. Rushdie, who was living in England then went into hiding and lived so for over a decade, changing houses very often. He won his freedom only recently in the year 2000 when the "fatwa" was officially called off by Iran. After the lifting of the fatwa, he also decided to migrate to the US, feeling quite bitter at the way the British government, he felt, had failed to stand up to Iran and get the fatwa annulled.

The book that he first wrote in writing was Haroun and the Sea of Stories (1990). It is Rushdie's answer to Imam Khomeini and his other tormentors. The book is a delightful 
children's story on one level but on the other, it is the story of his forced imprisonment in an unknown place and the silence imposed on him by the sentence of death passed by Ayatollah Khomeini. Khomeini is portrayed in the character of King Khattam Shud who is the archenemy of all stories and the Foe of Speech.

East West (1994) is a collection of short stories. The second book that Rushdie wrote in writing was The Moor's Last Sigh (1995), his fifth novel; and again highly controversial. The book was first banned in India and then released a couple of months later. The cause of the ban was Rushdie's open attack on Bal Thackeray, leader of the Shiv Sena. In the novel, the narrator Moraes Zogoby is exiled twice. Once, when his mother turns him out of her house in Bombay and next when the forces of operation seek him and he escapes to Spain. It is the story of a character on the run. One of the most poignant and autobiographical descriptions in The Moor's Last Sigh is the one in which Moraes fears he will lose his sanity in the imprisonment imposed on him by his tormentors. Thus, apart from thematic clarifications of a general nature, this introduction to his works helps us to a basic summation that almost all of Salman Rushdie's have a nostalgic look backwards.

It is unfortunate that many Third World writers have been migrating to the metropolitan cities of London, Paris and New York to find a marketing for their works. It is also unfortunate that that a work of art is functioning not according to aesthetic standards, but what Adorno called "culture industry" whereby vulgar economics and politics begins to govern works of art. The impact of colonization on their psyche is so tremendous that they feel that the great traditions of "culture" and "civilization" exist only in the west and that its literatures were superior to our own. But, these migrants who stay away from their home country, begin to experience an acute sense of homelessness and anxiety after the initial 
pleasures of being in a new land fade away. They are discriminated on the basis of colour and race.

George Lamming, in his non-fictional work, The Pleasures of Exile has written with sensitivity and highlights the terrible dilemma and the divided feelings that a writer or a migrant from the Third World experiences in the West. The dilemma is: it is painful to stay but it is as difficult to return. Interestingly, most migrants try to cope with this sense of homelessness and rejection and their own inability to return, by over-idealization of home, or by the use of satire. Thus, either they tend to praise their mother country in superlatives or they satirize it and poke fun at its flaws to justify why they can't return. Rushdie belongs to the category of these typical migrants.

But Rushdie's situation is also a fluid-situation. That Rushdie's location is fluid is easily explainable when he declares himself to be inhabiting the "in-between world" in his book, Imaginary Homelands. The consistent shifting of his space has a lot with his longing for real but imaginary homelands. "The post-modernist fiction so much after the discourse of post-modernism, validates the imaginary or the virtual over the real. Rushdie considers himself one of the emigrant writer, who writes about India imaginatively." The representation of the real in fiction is, and has always been an imaginative re-creation. What, Rushdie, however, stresses is his sense of alienation from the subcontinental realities even while claiming to represent the reality imaginatively." Rushdie states: "' It may be writers in my position, exiles or emigrants or expatriates, are haunted by some sense of loss, some urge to reclaim, to look back, even at the risk of being mutated into pillars of salt. But if we do look back, we must also do so in the knowledge- which gives rise to profound uncertaintiesthat our physical alienation from India almost inevitably means that we will not be capable of reclaiming precisely the thing that was lost; that we will, in short, create fictions, not actual cities or villages, but invisible ones, imaginary homelands, India of the mind.'(p.10) 
In Rushdie's view, an outsider can approach the reality in a much more artistic and meaningful manner than an insider. Rushdie comments on his pluralistic identity as:

"Our identity is at once plural and partial, sometimes we feel that we straddle two cultures; at other times that we fall between two cultures; at other times that we fall between two stools. But however, ambiguous and shifting this ground may be, it is not an infertile territory for a writer to occupy. If literature is in part the business of finding new angles at which to enter reality, then once again our distance, our long geographical perspective, may provide us with such angles. Or it may be that is simply what we must think in order to do our work."' (P.15-16)

These quotations from his work illustrate that Rushdie kept himself deliberately away from his native-country. It was his own choice to maintain a distance from the sub-continent.

Aijaz Ahmad, in his work 'In Theory', states that 'Rushdie's idea of 'migrancy', for example, which is quite central to his self-representation both in fiction and in life, and has come to us in two versions. In the first version...'migrancy' is given to us as an ontological condition of all human beings, while the 'migrant' is said to have 'floated upwards from history.' In the second version, articulated more fully in the more recent writings, this myth of ontological unbelonging is replaced by another, larger myth of excess of belongings; not that the he belongs nowhere, but that he belongs to too many places....”(p.127)

He further states that, "What is new in the contemporary metropolitan philosophies and the literary ideologies which have arisen since the 1960s, in tandem with vastly novel restructurings of global capital investments, communication systems and information networks- not to speak of actual travelling facilities- is that the idea of belonging is itself being abandoned as antiquated false consciousness." (p.129). The writer has all the cultures available to him or her as resource, for consumption, but he or she actually belongs in all of them, by virtue of belonging properly in none. Rushdie puts it quite succinctly: "the ability to 
see at once from inside and out is a great thing, a piece of good fortune which the indigenous writer cannot enjoy."

This is a pointer to the fact Rushdie was not, until the macabre sentencing by Ayatollah Khomeini in an exile but a self-exile. To quote Rushdie again, "Writers in exile often write primarily for readerships which are materially absent from the immediate conditions of their production, present only in the country from which the writer has been forcibly exiled, hence all the more vividly and excruciatingly present in the writer's imagination because their actuality is deeply intertwined with the existential suffering of exile and with the act of writing as such. The self-exile has no such irrevocable bond, he is free to choose the degree of elasticity of that bonding, and the material consequences of his migrancy necessarily bring him into a much more accountable relation with the readership which is materially present within the milieu of his productive work."(p.131).

Even a brief critical overview of Rushdie's words is sufficient to conclude that almost all the critics accept Rushdie's role as a cultural informant and interpreter without any reservations. Thus, to Goonetilleke, Rushdie "has roots in India, Pakistan and Britain, finds the cultural riches of two hemispheres cross-fertilizing, and evolves a mode of writing particularly suited to global culture."(148). The important element to note in this particular case is that the critics accept Rushdie as a culmination of East-West cultures and has no doubts in accepting the generalization of the so-called global culture. To Catherine Cundy, Rushdie's fiction “interweaves contemporary and mythical 'reality' benefiting from what the writer himself has termed the 'cultural accumulation of myth.'" (3). As can be noted in Cundy's statement, she also allows, or assumes, the in-depth knowledge of contemporary India and of the cumulative mythologies-past and present-thus granting Rushdie an undisputed role of a mega-culture pundit and interpreter in a temporal arena. 
Rushdie penetrates his own primary culture and, through his characters, tends to indict the culture in which the stories are set. The author's degree of removal from the area of contention, from the so-called Ground Zero, is not quite remote. He is at the most either inside the subject culture, or at least in the close proximity of it. There would be nothing wrong in stating that, concerning the knowledge of the exotic locals of his fictions, Rushdie is attributed the same kind of authority most of the oriental scholars enjoyed in the hey-day of orientalism but what the critics fail to express, or choose not to express, is that Rushdie visits his primary culture, and then writes about it. It is summed up in Edward Said's words, "as a constructed figure, not as a true self." (Orientalism 171). Masood Raza writes, "This implies that, while Rushdie's "true self" might be the one determined by his lived experiences in the West and his Eastern heritage, his constructed is the one that is viewed as that of a learned culture informant who is expected to represent the East (India and Pakistan) to the West. Thus, Rushdie's true self would turn out to be a self that can combine moods and norms of various cultures in one person." He writes that "when Rushdie writes about Islam, or about the Subcontinent, his imagines reality is considered to be true, simply because of the cultural knowledge and understanding attributed to him. It is, therefore, important to figure out how far this assumption about his role as a cultural informant can hold true, for it does not, then his fictions would have an altogether altered, or misconstrued, meaning." (p. 13)

If we look inside his book, Shame, the narrative in the novel is controlled transparently by repeated, direct, personal interventions by the narrator, (i.e.) Rushdie himself. He writes in Shame, "I tell myself this will be a novel of leave-taking, my last words in the East from which, many years ago, I began to come loose. I do not always believe myself when I say this. It is a part of the world to which, whether I like it or not, I am still joined, if only by elastic bonds." (p.23). Another line from the same book states, "I, too, am a translated man. I have been borne across." (pp. 23-4). This is a direct pointer to his self-exile. 
And finally:

"What is the best thing about migrant people and seceded nations? I think it is their hopefulness... And what is the worst thing? It is the emptiness of one's luggage... We have floated upwards from history, from memory, from Time.” (pp. 70.71)

Rushdie states in an interview that he had left Pakistan not because of political difficulty or economic pressure but because he found the country 'suffocating' and 'claustrophobic'.

There is a quality of linguistic quicksand in all such passages, as if the truth of each utterance were conditioned by the existence of its opposite and Rushdie seems forever to be taking with one hand what he has given with the other: the will to take leave is poised against the impossibility of leave taking; he has been coming loose but he is still 'joined'; he is still joined but only by elastic bonds, and he is not sure that he likes the fact of continued joining; he makes statements but he does not believe in them; the fictive and the real coexists 'at a slight angle to reality'; not only his text but he is 'translated', ' borne across'; the translation occurs not on the semantic but on the existential level. (p. 13)

The writing of The Satanic Verses resulted in the unleashing of a great fundamentalist fury against him, and it made the non-elasticity of bonds vivid in a gruesome way. Rushdie was forced to into hiding, a kind of an imposed exile rather than the initial self-imposed exile. Khomeini's sentencing of him, turned paradoxically and tragically, into a full-scale exile.

There is an interrelationship between his life, social experience, imagined nationality, global-culture, his life in exile and in his works. He has been successful to transfigure and lense the reality of his life and experience into his novels.

In the end, a comment on Rushdie's implications of the condition he actuality finds himself in is from his essay, 'Outside the Whale', where he uses the metaphor of a whale's belly to indicate the whole space the Indian occupies. He writes: 
"Outside the whale is the unceasing storm, the continual quarrel, the dialectical of history. Outside the whale is a genuine need for political fiction, for books that draw new and better maps of reality, and make new languages with which we can understand the world. Outside the whale we see that we are all irradiated by history, we are radioactive with history and politics; we see that it can be as false to create a politics-free fictional universe as to create one in which nobody needs to work or eat or love or sleep. Outside grapple with the special problems politics is by turns force and tragedy, and sometimes (e.g. Zia's Pakistan) both at once. Outside the whale, the writer is obliged to accept that he (or she) is part of the crowd, part of the ocean, part of the storm, so that objectivity becomes a great dream, like perfection, unattainable goal for which one must struggle inspite of the impossibility of success. Outside the whale is the world of Samuel Beckett's famous formula: "I can't go on, I'll go on." (pp. 100-101) 


\section{Works Cited}

Edward Said, Reflections on Exile and other literary and cultural essays, Penguin Books India Ltd., New Delhi, 2001.

James Joyce, Dubliners, XX-XXI.

Gillian Rose, The Melancholic Science, An Introduction to the Thought of Theodor. W. Adorno. London: The Macmillan Press. 1978

Aijaz Ahmad, In Theory:Classes, Nations, Literatures, Oxford University Press, New Delhi, 2002.

Salman Rushdie, Imaginary Homelands: Essays and Criticism 1981-1991, London, Granta, 1991.

D. C. R. A. Goonetilleke, Salman Rushdie, 1998.

Catherine Cundy, Salman Rushdie, 1998.

Salman Rushdie,Shame, Picador, London, 1983. 